\title{
Antimicrobial effects of Indian medicinal plants against acne-inducing bacteria
}

\author{
GS Kumar ${ }^{1 *}, \mathrm{KN}$ Jayaveera ${ }^{2}, \mathrm{CK}$ Ashok Kumar ${ }^{3}$, Umachigi P \\ Sanjay $^{4}$, BM Vrushabendra Swamy ${ }^{5}$, DV Kishore Kumar ${ }^{6}$.
}

${ }^{1}$ Department of Chemistry (K.N.J) Jawaharlal Nehru Technological Üniversity College of Engineering, Ananthpur- 01, Andhra Pradesh, India. ${ }^{2}$ Department of Pharmacognosy (G.S.K), ${ }^{3}$ Department of Pharmaceutics (U.P.S), ${ }^{4}$ Department of Pharmacology (B.M.V.S), ${ }^{5}$ Department of Chemistry (D.V K.K), Rural College of Pharmacy, D.S.Road, Devanahalli-562110 Karnataka, India. ${ }^{6}$ Department of Pharmacognosy (A.K.C.K) Sree Vidyanikethan, College of Pharmacy, A.Rangamepeta, Chittoor Dist, Andhra Pradesh, India.

\begin{abstract}
Propionibacterium acnes and Staphylococcus epidermidis have been recognized as pus-forming bacteria triggering an inflammation in acne. The present study was conducted to evaluate antimicrobial activities of Indian medicinal plants against these etiologic agents of acne vulgaris. Ethanolic extracts of Hemidesmus indicus (roots), Eclipta alba (fruits), Coscinium fenestratum (stems), Curcubito pepo (seeds), Tephrosia purpurea (roots), Mentha piperita (leaves), Pongamia pinnata (seeds), Symplocos racemosa (barks), Euphorbia hirta (roots), Tinospora cordyfolia (roots), Thespesia populnea (roots), and Jasminum officinale (flowers) were tested for antimicrobial activities by disc diffusion and broth dilution methods. The results from the disc diffusion method showed that 07 medicinal plants could inhibit the growth of Propionibacterium acnes. Among those Hemidesmus indicus, Coscinium fenestratum, Tephrosia purpurea, Euphorbia hirta, Symplocos racemosa, Curcubito pepo and Eclipta alba had strong inhibitory effects. Based on a broth dilution method, the Coscinium fenestratum extract had the greatest antimicrobial effect. The MIC values were the same $(0.049 \mathrm{mg} / \mathrm{ml})$ for both bacterial species and the MBC values were 0.049 and $0.165 \mathrm{mg} / \mathrm{ml}$ against Propionibacterium acnes and Staphylococcus epidermidis, respectively. In bioautography assay, the Coscinium fenestratum extract produced strong inhibition zones against Propionibacterium acnes. Phytochemical screening of Coscinium fenestratum revealed the presence of alkaloid which could be responsible for activity. Taken together, our data indicated that Coscinium fenestratum had a strong inhibitory effect on Propionibacterium acnes and Staphylococcus epidermidis.
\end{abstract}

Keywords: Acne; Propionibacterium acnes; Staphylococcus epidermidis; Antimicrobial activity

*Correspondence: E-mail: pharmacygsk@rediff.com, kumar_cog@yahoo.com 


\section{INTRODUCTION}

Acne vulgaris is a most common skin disorder of Pilosebaceous unit. That affects areas containing the largest oil glands, including the face, back, and trunk ${ }^{1}$. It is generally characterized by formation of seborrhea, comedone, inflammatory lesions and presence of bacteria Propionibacterium acnes, Staphylococcus epidermidis and Malassezia furfur in the follicular canal and sebum production ${ }^{2}$. Propionibacterium acnes have been described as an obligate anaerobic organism. It is implicated in the development of inflammatory acne by its capability to activate complements and by its ability to metabolize sebaceous triglycerides into fatty acids, which chemotactically attract neutrophils. On the contrary, Staphylococcus epidermidis, an aerobic organism, usually involves in superficial infections within the sebaceous unit ${ }^{3}$. These factors provide a potential target for treatment. Propionibacterium acnes and Staphylococcus epidermidis are the target sites of antiacne drugs $^{4,5}$. Long term use of antibiotics against acne is outdated because of exacerbated antibiotic resistance ${ }^{6,7}$. The development of antibiotic resistance is multifactorial, including the specific nature of the relationship of bacteria to antibiotics, how the antibacterial is used, host characteristics, and environmental factors. To overcome the problem of antibiotic resistance, medicinal plants have been extensively studied as alternative treatments for diseases. In the present study, 12 medicinal plants, which have been traditionally used as antimicrobial and antiinflammatory agents were examined for antimicrobial activities against microorganisms frequently involved in acne inflammation, Propionibacterium acnes and Staphylococcus epidermidis.

\section{MATERIALS AND METHODS}

Plant material

The 12 plant materials used in this study were collected from various locations in India. Authentication of the plant materials was done by comparison with plant specimens located at Bangalore. Herbarium and Botanical Section of Regional Research Institute (Ayurveda),
Jaynagar, Bangalore. The specimens were deposited at Department of Pharmacognosy, Rural College of Pharmacy, Devanahalli, Bangalore Rural District, Karnataka, India.

\section{Microorganisms and media}

The test organisms used in this study were as followed: Propionibacterium acnes (MTCC 1951) and Staphylococcus epidermidis (MTCC 931). These bacteria were obtained

from the Microbial Type Culture Collection and Gene Bank, Chandigarh, India All media were purchased from Himedia.

\section{Preparation of plant extracts}

Dried parts of the plants were made into coarse powder. $400 \mathrm{~g}$ Hemidesmus indicus(roots, $24.2 \% \mathrm{w} / \mathrm{w}$ ), Eclipta alba (fruits, $13.1 \% \mathrm{w} / \mathrm{w}$ ), Coscinium fenestratum (stems, $20.4 \% \mathrm{w} / \mathrm{w}$ ), Curcubito pepo (seeds, 17.9\% w/w), Tephrosia purpurea (roots, $6.9 \% \mathrm{w} / \mathrm{w}$ ), Mentha piperita (leaves, $14.3 \% \mathrm{w} / \mathrm{w}$ ), Pongamia pinnata (seeds, $23.1 \% \mathrm{w} / \mathrm{w}$ ), Symplocos racemosa (barks, $19.5 \% \mathrm{w} / \mathrm{w}$ ), Euphorbia hirta (roots, $17.4 \% \mathrm{w} / \mathrm{w}$ ), Tinospora cordyfolia (roots, $18.4 \% \mathrm{w} / \mathrm{w}$ ), Thespesia populnea (roots, $17.6 \% \mathrm{w} / \mathrm{w}$ ), and Jasminum officinale (flowers, $12.5 \% \mathrm{w} / \mathrm{w}$ ) were macerated in ethanol. The macerate was filtered after seven consecutive days, filtrate was dried under reduced pressure and finally under vaccum desicator.

\section{Antimicrobial susceptibility testing \\ Disc diffusion method}

This experiment was performed by the method of Hayes and Markovic ${ }^{8}$ with some modifications. Propionibacterium acnes was incubated in brain heart infusion medium $(\mathrm{BHI})$ with $1 \%$ glucose for $48 \mathrm{~h}$ under anaerobic conditions and adjusted to yield approximately $1.0 \times 10^{8} \mathrm{CFU} / \mathrm{ml}$. Aliquots of molten $\mathrm{BHI}$ with glucose agar were used as the agar base. A prepared inoculum was added to the molten agar, mixed, poured over the surface of the agar base and left to solidity. A sterile paper disc was impregnated with test material $(100 \mathrm{mg} / \mathrm{ml})$.and placed on the agar. Clindamycin $(10 \mu \mathrm{g} / \mathrm{ml})$ was used as the standard. The plates were then incubated at $37^{\circ} \mathrm{C}$ for $48 \mathrm{~h}$ under anaerobic 
Kumar et al

TABLE 1: Antimicrobial Activity of Medicinal Plant Extracts

\begin{tabular}{|c|c|c|}
\hline \multirow[t]{3}{*}{ Plant extracts } & \multirow{2}{*}{\multicolumn{2}{|c|}{$\begin{array}{l}\text { Susceptibility of bacteria to medicinal plant extracts } \\
\qquad \text { Zone of inhibition }(\mathrm{mm})^{a_{*}}\end{array}$}} \\
\hline & & \\
\hline & Propionibacterium acnes & Staphylococcus epidermidis \\
\hline Hemidesmus indicus & 13 & 14 \\
\hline Eclipta alba & 12 & 10 \\
\hline Coscinium fenestratum & 15 & 16 \\
\hline Curcubito pepo & 12 & 14 \\
\hline Tephrosia purpurea & 12 & 13 \\
\hline Mentha piperita & 08 & 12 \\
\hline Pongamia pinnata & 08 & 09 \\
\hline Symplocos racemosa & 14 & 14 \\
\hline Euphorbia hirta & 13 & 12 \\
\hline Tinospora cordyfolia & 07 & 06 \\
\hline Thespesia populnea & 05 & 05 \\
\hline Jasminum officinale & 06 & 07 \\
\hline Clindamycin & 19 & 20 \\
\hline
\end{tabular}

conditions in an anaerobic jar (Hi-Media) with gas pack and indicator strip and the jar was kept in an incubator for $48 \mathrm{~h}$ at $37 \pm 1^{\circ} \mathrm{C}$. Gas packs containing citric acid, sodium carbonate and sodium borohydride were used to maintain and check the anaerobiosis, where citric acid releases carbon dioxide and sodium borohydride releases hydrogen when they come in contact with oxygen. An indicator strip of methylene blue, when introduced into the jar, changes in colour from white to blue in the absence of anaerobiosis. Staphylococcus epidermidis was incubated in tryptic soy broth (TSB) for $24 \mathrm{~h}$ at $37^{\circ} \mathrm{C}$ and adjusted to yield approximately $1.0 \times 10^{8} \mathrm{CFU} / \mathrm{ml}$. The procedures were the same as mentioned above except the plates were incubated at $37^{\circ} \mathrm{C}$ for $24 \mathrm{~h}$ under aerobic conditions. All disc diffusion tests were performed in three separate experiments and antibacterial activity was expressed as the mean of inhibition diameters ( $\mathrm{mm}$ ) (see Table 1).
Determination of minimum inhibitory and bactericidal concentrations

The minimal inhibitory concentration (MIC) values were determined by broth dilution assay ${ }^{9}$ 10,11 . The cultures were prepared at $24 \mathrm{~h}$ and 48 $\mathrm{h}$ broth cultures of Staphylococcus epidermidis and Propionibacterium acnes, respectively. The MIC was defined as the lowest concentration of the compound to inhibit the growth of microorganisms.

$3 \mathrm{ml}$ of the Nutrient yeast glucose broth (NYG) for Propionibacterium acnes, and Nutrient broth for Staphylococcus epidermidis, in $10 \mathrm{ml}$ glass screw cap test tube was sterilised by autoclaving at $121^{\circ} \mathrm{C}$ for $15 \mathrm{~min}$. The medium was cooled and inoculated with $50 \mu \mathrm{l}$ of the bacterial suspension containing $1 \times 10^{8}$ cells $/ \mathrm{ml}$. $1 \mathrm{ml}$ of the plant extracts $(100 \mathrm{mg} / \mathrm{ml})$ was added to corresponding test tubes under anaerobic condition. $3 \mathrm{ml}$ of NYG broth inoculated with $50 \mu \mathrm{l}$ 
of organisms was taken as positive control. The test tubes were then kept in anaerobic jar (HiMedia) with gas pack and indicator strip and the jar was kept in incubator for $48 \mathrm{~h}$ at $37 \pm 1^{\circ} \mathrm{C}$. Gas packs containing citric acid, sodium carbonate and sodium borohydride were used to maintain and check the anaerobiosis, where citric acid releases carbon dioxide and sodium borohydride releases hydrogen when they come in contact with oxygen. An indicator strip of methylene blue, when introduced into the jar, changes in colour from white to blue in the absence of anaerobiosis. For Staphylococcus epidermidis, the test tubes were incubated at 37 $\pm 1^{\circ} \mathrm{C}$ for $24 \mathrm{~h}$ aerobically and growth of Propionibacterium acnes and Staphylococcus epidermidis was measured as a function of turbidity at $660 \mathrm{~nm}$ using (Systronics 131) Nephaloturbidometer. The MIC and MBC values of 12 medicinal plant extracts against Propionibacterium acnes and Staphylococcus epidermidis were determined. The results are shown in Table 2 as average values from three separate experiments per medicinal plants and indicate the susceptibility of bacteria to the medicinal plant extracts.

\section{Phytochemical screening ${ }^{12}$}

The ethanolic extract was subjected to preliminary phytochemical testing for the detection of major chemical groups. The details of the tests are as follows:

1. For phenols: The ethanolic extract was spotted on a filter paper. A drop of phoshomolybdic acid reagent was added to the spot and was exposed to ammonia

Vapours (Blue coloration of the spot indicates the presence of phenols).

2. Braemer's test for tannins: To a $2-3 \mathrm{ml}$ of methanolic extract, $10 \%$ alcoholic ferric chloride solution was added. (Dark blue or greenish grey coloration of the solution indicate the presence of tannins in the drug).

3. Liebermann-Burchardt test for steroids and terpenoids: To $1 \mathrm{ml}$ of methanolic extract of drug, $1 \mathrm{ml}$ of chloroform, 2-3 $\mathrm{ml}$ of acetic anhydride and 1 to 2 drops of concentrated sulfuric acid were added. (Dark green coloration of the solution indicate the presence of
Steroids and dark pink or red coloration of the solution indicate the presence of terpenoids).

4. Alkaloids: A drop of methanolic extract was spotted on a small piece of precoated TLC plate and the plate was sprayed with modified Dragendorff's reagent. (Orange coloration of the spot indicates the presence of alkaloids).

5. Bornträger's test for anthraquinones: About 50 $\mathrm{mg}$ of methanolic extract was heated with $10 \%$ ferric chloride solution and $1 \mathrm{ml}$ of concentrated hydrochloric acid. The extract was cooled, filtered and the filtrate was shaken with diethyl ether. The ether extract

was further extracted with strong ammonia. (Pink or deep red coloration of aqueous layer indicate the presence of anthraquinones).

6. Shinoda test for flavonoids: To $2-3 \mathrm{ml}$ of methanolic extract, a piece of magnesium ribbon and $1 \mathrm{ml}$ of concentrated hydrochloric acid were added. (Pink red or red coloration of the solution indicate the presence of flavonoids in the drug).

\section{Bioautography}

Bioautography was performed with bacterial cultures exhibiting high sensitivity to the extracts. Developed TLC plates were carefully dried for complete removal of solvent, overlaid with agar containing an aliquot of an overnight culture and incubated at $37 \circ \mathrm{C}$. The plates were run in duplicate; one set was used as the reference chromatogram and the other was used for bioautography.

\section{RESULTS}

In the present study, 12 medicinal plant extracts were examined for antimicrobial activity against Propionibacterium acnes and Staphylococcus epidermidis. The results showed that 07 extracts could effectively inhibit the growth of Propionibacterium acnes. Among these, ethanolic extracts of Hemidesmus indicus, Eclipta alba, Coscinium fenestratum, Curcubito pepo, Symplocos racemosa, Euphorbia hirta and Tephrosia purpurea showed strong inhibitory effects Table 1) Interestingly, Coscinium fenestratum, Hemidesmus indicus, and Symplocos racemosa extracts showed promising antibacterial activities against both Propionibacterium acnes and Staphylococcus epidermidis. The remaining 5 plant extracts had 
Table 2: The MIC and MBC values of 12 medicinal plant extracts against Propionibacterium acnes and Staphylococcus epidermidis. The results are shown as mean of triplicate measurements

\begin{tabular}{|c|c|c|c|c|}
\hline \multirow[t]{3}{*}{ Plant extracts } & \multicolumn{4}{|c|}{ Susceptibility of bacteria to medicinal plant extracts ${ }^{\mathrm{a}}$} \\
\hline & \multicolumn{2}{|c|}{ Propionibacterium acnes } & \multicolumn{2}{|c|}{ Staphylococcus epidermidis } \\
\hline & $\begin{array}{c}\mathrm{MIC} \\
(\mathrm{mg} / \mathrm{ml})\end{array}$ & MBC (mg/ml) & MIC (mg/ml) & MBC (mg/ml) \\
\hline $\begin{array}{l}\text { Hemidesmus } \\
\text { indicus }\end{array}$ & 0.051 & 2.5 & 1.25 & $>4$ \\
\hline Eclipta alba & 0.665 & $>5$ & 0.312 & $>5$ \\
\hline $\begin{array}{l}\text { Coscinium } \\
\text { fenestratum }\end{array}$ & 0.049 & 0.049 & 0.049 & 0.165 \\
\hline Curcubito pepo & 1.25 & 1.25 & 2.5 & 5 \\
\hline $\begin{array}{l}\text { Tephrosia } \\
\text { purpurea }\end{array}$ & 0.675 & 1.25 & 2.5 & $>5$ \\
\hline Mentha piperita & $>5$ & $>5$ & $>5$ & $>5$ \\
\hline $\begin{array}{l}\text { Pongamia } \\
\text { pinnata }\end{array}$ & 2.5 & $>5$ & 2.5 & $>5$ \\
\hline $\begin{array}{l}\text { Symplocos } \\
\text { racemosa }\end{array}$ & 0.685 & 1.35 & 0.685 & $>4$ \\
\hline Euphorbia hirta & 1.55 & 1.95 & 2.5 & 5 \\
\hline $\begin{array}{l}\text { Tinospora } \\
\text { cordyfolia }\end{array}$ & 5 & 5 & 5 & $>5$ \\
\hline $\begin{array}{l}\text { Thespesia } \\
\text { populnea }\end{array}$ & $>5$ & $>5$ & $>5$ & $>5$ \\
\hline $\begin{array}{l}\text { Jasminum } \\
\text { officinale }\end{array}$ & 5 & $>5$ & $>5$ & $>5$ \\
\hline Clindamycin* & 78 & 85 & 76 & 72 \\
\hline
\end{tabular}

no detectable activity against Staphylococcus epidermidis. Subsequent experiments were conducted to determine inhibitory concentrations of all selected plant extracts. Coscinium fenestratum showed the potent antimicrobial effect. The MIC values against both organisms were equal $(0.049 \mathrm{mg} / \mathrm{ml})$ and the $\mathrm{MBC}$ values were 0.049 and $0.165 \mathrm{mg} / \mathrm{ml}$ against Propionibacterium acnes and Staphylococcus epidermidis, respectively (Table 2). Further, the plant extracts was subjected to preliminary Phytochemical screening for the presence and absence of different chemical groups (Table 3).

\section{DISCUSSION}

The similar values of MIC and MBC obtained from this plant against Propionibacterium acnes suggest that the ethanolic extract of Coscinium 
Kumar et al

Table 3: Preliminary phytochemical screening of 12 medicinal plant extracts

\section{Plant extracts Phenols Tannins Steroids Alkaloids Glycosides Flavonoids Terpenoids}

\begin{tabular}{|c|c|c|c|c|c|c|c|}
\hline $\begin{array}{l}\text { Hemidesmus } \\
\text { indicus }\end{array}$ & +++ & ++ & -- & -- & + & +++ & ++ \\
\hline Eclipta alba & ++ & +++ & -- & -- & -- & +++ & + \\
\hline $\begin{array}{l}\text { Coscinium } \\
\text { fenestratum }\end{array}$ & ++ & -- & -- & +++ & -- & +++ & + \\
\hline $\begin{array}{l}\text { Curcubito } \\
\text { pepo }\end{array}$ & + & ++ & ++ & -- & + & + & + \\
\hline $\begin{array}{l}\text { Tephrosia } \\
\text { purpurea }\end{array}$ & + & -- & + & -- & ++ & +++ & -- \\
\hline $\begin{array}{l}\text { Mentha } \\
\text { piperita }\end{array}$ & + & -- & ++ & -- & -- & -- & +++ \\
\hline $\begin{array}{l}\text { Pongamia } \\
\text { pinnata }\end{array}$ & -- & -- & ++ & ++ & -- & -- & ++ \\
\hline $\begin{array}{l}\text { Symplocos } \\
\text { racemosa }\end{array}$ & -- & ++ & ++ & +++ & ++ & -- & -- \\
\hline $\begin{array}{l}\text { Euphorbia } \\
\text { hirta }\end{array}$ & ++ & ++ & -- & -- & + & +++ & -- \\
\hline $\begin{array}{l}\text { Tinospora } \\
\text { cordyfolia }\end{array}$ & + & -- & + & +++ & -- & ++ & + \\
\hline $\begin{array}{l}\text { Thespesia } \\
\text { populnea }\end{array}$ & -- & -- & + & +++ & + & -- & -- \\
\hline $\begin{array}{l}\text { Jasminum } \\
\text { officinale }\end{array}$ & ++ & -- & -- & -- & -- & +++ & +++ \\
\hline
\end{tabular}

$-=$ absent $;+=$ Trace $;++=$ moderate,$+++=$ Abundant

fenestratum could possibly act as a bactericidal agent to this microorganism. In addition, the Hemidesmus indicus extract also showed good antimicrobial effects against Propionibacterium acnes with a MIC of $0.051 \mathrm{mg} / \mathrm{ml}$ but a high concentration was required to kill both Propionibacterium acnes and Staphylococcus epidermidis as compared to the ethanolic extract of Coscinium fenestratum. Symplocos racemosa, showed outstanding antimicrobial properties against Propionibacterium acnes based on the disc diffusion assay, each had a MIC value of $0.685 \mathrm{mg} / \mathrm{ml}$ and a MBC of 1.35 $\mathrm{mg} / \mathrm{ml}$ for Propionibacterium acnes. The plant extracts were further analyzed by phytochemical screening for detection of phytoconstituents. The assay for bioautography demonstrated strong inhibition zones of Coscinium fenestratum extract against the growth of Propionibacterium acnes. The clear zones were located in separate places on the TLC plate, suggesting that more than one compound possessed an antimicrobial effect. There were no inhibition zones presented above the bands of the other plant extracts covered with Propionibacterium acnes. This implied that the strongest effect of the Coscinium fenestratum extract was against Propionibacterium acnes. Phytochemical screening of Coscinium fenestratum extract showed positive results for the presence of alkaloids. Alkaloid and its derivatives have activities against Staphylococcus aureus and methicillin-resistant $S$. aureus ${ }^{13}$. The mechanism of action of highly aromatic planar quaternary alkaloids such as berberine and harmane $^{14}$ is attributed to their ability to intercalate with $\mathrm{DNA}^{15}$. It is possible that berberine an alkaloid present in Coscinium fenestratum may act in the same mechanism to inhibit Propionibacterium acnes and 
Staphylococcus epidermidis. Therefore, the active component of the Coscinium fenestratum extract could be of interest for further development as an alternative treatment for acne.

\section{REFERENCES}

1. Leyden JJ. Therapy for Acne vulgaris. The New Eng J Med 1997; 156-1162.

2. Leyden JJ. Current issues in antimicrobial therapy for the treatment of acne. J Eur Dermatol Venereol 2001; 15(3):51-55

3. Burkhart CG., Burkhart CN., Lehmann PF.. Acne: a review of immunologic and microbiologic factors. J Post grad Med 1999; 75: 328-331.

4. Leyden JJ. The evolving role of Propionibacterium acnes in acne. Semin Cutan Med Surg 2001; 20:139-143.

5. Hamnerius N. Acne-aetiology and pathogenesis. Treatment of Acne 1996; 32: 29-38.

6. Degroot HE, Friedlander SF. "Update Acne". Curr Opin Pediatr 1998; 10: 381-386.

7. Swanson IK. Antibiotic resistance of Propionibacterium acnes in Acne vulgaris. Dermatol Nurs 2003; 5: 359-361.
8. Hayes AJ, Markovic B. Toxicity of Australian essential oil Backhousia citriodora (Lemon myrtle). Part 1 Antimicrobial activity and in vitro cytotoxicity. Food Chem Toxicol 2002; 40: 535- 543.

9. Isao Kubo, Hisae Muroi, Aya Kubo. Naturally occurring antiacne agents. J Nat Prod 1994; 57(1): 9-1 7

10. Sahin F, Karaman I, Gulluce M, Ogutcu H, Sengul M, Adiguzel A, Ozturk, S, Kotan R. Evaluation of antimicrobial activities of Satureja hortensis L. J Ethnopharmacol 2003; 87: 61-65.

11. Kumar GS, Salma khanam. Antiacne activity of few natural products. Ind J Nat Prod 2004; 30(4): 7-9.

12. Ravishankara $M N$, Neeta $S$, Harish Padh, Rajani $M$ Evaluation of antioxidant properties of root bark of Hemidesmus indicus R. Br. (Anantmul) Phytomed 2002; 9: 153-160.

13. Valsaraj R, Pushpangadan $P$, Smitt UW, et. al Antimicrobial screening of selected medicinal plants from India. J Ethnopharmacol 1997; 58: 7583.

14. Hopp KH, Cunningham LV,. Bromel MC, Schermeister LJ Wahba Khalil SK. In vitro antitrypanosomal activity of certain alkaloids against Trypanosoma lewisi. Lloydia 1976;39: 375-377.

15. Phillipson JD, Neill MJO.. New leads to the treatment of protozoal infections based on natural product molecules. Acta Pharm Nord 1987; 1: 131-144. 